\title{
Arsenic in forests - a short review
}

\author{
Panagiotis Michopoulos"
}

\author{
H.A.O. DEMETER-Institute of Mediterranean Forest Ecosystems, \\ TermaAlkmanos, Athens 115 28, Greece
}

\begin{abstract}
Michopoulos, P., 2021. Arsenic in forests - a short review. Folia Oecologica, 48 (1): 35-41.

The inputs of As in forest ecosystems have declined since the eighties when the higher concentrations of that metalloid were observed due to industrial activities. The As inputs to the forest floor include throughfall and litterfall where dry deposition is an appreciable percentage. This is manifested by the higher As concentration in older needles of conifers and the enrichment of throughfall relative to the bulk deposition. The throughfall and the forest floor convert the inorganic As into methylated organic As and in this way reduce its toxicity. In unpolluted forests the vast percentage of As is retained in soils because the oxides of $\mathrm{Fe}$ and $\mathrm{Al}$ are very efficient holders. In polluted forested soils the As can become mobile and enrich the surface runoff waters approaching even the threshold value set by the World Health Organization. For this reason forest soils with high concentration of As due to former high loads should be monitored.
\end{abstract}

\section{Keywords}

arsenic, forest, hydrological cycle, litterfall, soil, vegetation

\section{Introduction}

Inorganic arsenic is considered a potential human carcinogen, and humans are exposed to it from soil, water, air and food (Pradosh and SaHa, 2002; Bienert and JAHN, 2010). Arsenic contamination of groundwater, due to geogenic processes, is widespread and there are a number of regions where arsenic contamination of drinking water is significant. Arsenic problems in groundwater from the alluvial and deltaic aquifers of Bangladesh and West Bengal represent the most serious occurrences identified globally. Concentrations in groundwater from the affected areas have a very large range from 0.5 to $3,200 \mu \mathrm{g} \mathrm{L}^{-1}$ (KINNIBURGH and SMEDLEY, 2001).

The World Health Organization (WHO) provisional guideline value for As concentration drinking water is 10 $\mu \mathrm{g} \mathrm{L}^{-1}$ (WHO, 2020). Arsenic is also toxic to plants. ABBAS et al. (2018) described how As exposure adversely affects plants at biochemical and molecular levels. The authors conclude that many physiological responses, such as the overall growth processes, the photosynthetic efficiency and biomass are affected.

In natural ecosystems, As has four oxidation numbers: (III), (0), (+III) and (+V). Its various available chemical forms are arsenate $\{\mathrm{As}(\mathrm{V})\}$, arsenite $\{\mathrm{As}(\mathrm{III})\}$ and the organic compounds monomethyl tellat acid, dimethyl tellat acid, trimethyl arsine, arsenocholine, arsenobetaine, arsenosugars, etc. The inorganic arsenate $\mathrm{As}(\mathrm{V})$ and arsenite As(III) are the main phytoavailable forms of As in soil solution (KocH et al., 2000). Inorganic As is more toxic than the organic As, whereas As in the trivalent oxidation state is more toxic than that in the pentavalent state (MEHARG and HARTLEY-WHITAKER, 2002).

The average content of As in the continental crust of the Earth is generally given as $1.8 \mathrm{mg} \mathrm{kg}^{-1}$, and the global soil average As concentration is $6.83 \mathrm{mg} \mathrm{kg}^{-1}$ but soils vary a great deal (KaBATA-Pendias and Pendias, 2000). Despite the low concentration As, has accumulated in soils due

*Corresponding author: e-mail: mipa@fria.gr 
natural processes and (mainly) to anthropogenic activities. The natural processes involve inputs from wind and water erosion, volcanic emissions and marine aerosols. The anthropogenic sources include the use of arsenical pesticides, application of fertilizers, burning of fossil fuels, mining of As containing ores and disposal of industrial wastes (VAN HERREwEGHE et al., 2003). Anthropogenic As prevails in atmospheric emissions, while natural sources are close to negligible (Matschullat, 2000). Atmospheric As is mainly bound to fine aerosol particles $(<2.5 \mu \mathrm{m})$, which can be transported over long distances (CULLEN and REIMER, 1989). The subsequent As deposition enriches the organic surfaces of forest soils (STEINNES and FRIEDLAND, 2005). NYGARD et al. (2012) argued that the long-range atmospheric transport of As was a strongly contributing factor for As concentrations in soils in Norway from places out of the country.

It is a fact that the emissions of As have declined in Europe. The reduction was quantified by measurement of As in selected moss species. Mosses provide a surrogate, time-integrated measure of the spatial patterns and temporal trends of heavy metal deposition from the atmosphere to terrestrial ecosystems (HARMENs et al., 2007). Since the 1990 the As emissions in Europe dropped by 21\% in 2010 (HARmens et al., 2015). NovaK et al. (2011) found that the atmospheric inputs in forested catchments receiving heavy load of As in the past 30 years in the northern Czech Republic decreased even 40 times. Despite the decline in the As inputs, the organic horizons in soils in former polluted sites still hold As in high concentrations in comparison with forested sites that always had low input of As (NovAK et al., 2011). Forested catchments are sources of drinking water in many regions in the world. There are concerns that changes in pollution loads and climate can affect the solubility of As in soils (BAUER and BLODAU, 2009). For this reason, the study of As distribution and cycling in forests is important. There are excellent reviews with regard to the general role of As in soils and plants (MORENO-JiMÉNEZ, 2012), its toxicity in plants (ABBAs et al., 2018; PANDA et al. 2010), its dynamics in agronomic systems (PUNSHON et al. 2017), its distribution in natural waters (SMEDLEY and Kinniburgh, 2002), around the planet (MANDAL and SuZUKI, 2002; Matschullat, 2000) and its speciation in the environment (CULLEN and REIMER, 1989). The aim of this review is to elucidate the processes and contents of As in the compartments of forest ecosystems. The author decided to break down the review into the distribution of the element in the hydrological cycle, vegetation, litterfall, and forest soils.

\section{Hydrological cycle}

\section{Bulk and throughfall deposition}

NovAK et al. (2011) found rather high concentrations of As in the throughfall of beech (Fagus sylvatica L.) and Norway spruce (Picea abies (L.) Karst.) in the Czech Republic in both unpolluted $\left(270-0.430 \mu \mathrm{g} \mathrm{L}^{-1}\right)$ and industrial areas burning lignite $\left(600-700 \mu \mathrm{g} \mathrm{L}^{-1}\right)$, whereas the bulk depo- sition had an As concentration $0.36-0.500 \mu \mathrm{g} \mathrm{\textrm {L } ^ { - 1 }}$ in the unpolluted areas and $370-480 \mu \mathrm{g} \mathrm{L}^{-1}$ in the polluted ones. Michopoulos et al. (2018) found much lower concentrations (in both throughfall and bulk deposition) in a mountainous remote Bulgarian fir (Abies borisii-regis Mattf.) forest, with no history of pollution, in central Greece. The throughfall concentrations ranged from 0.11 to $1.01 \mu \mathrm{g} \mathrm{L}^{-1}$ and those of the bulk deposition 0.03 to $0.19 \mu \mathrm{g} \mathrm{L}^{-1}$. In the mountains close to the borders of the Czech Republic and Poland, Doušoví et al. (2007) determined the concentrations of As and its binding forms in bulk and interception deposition in the winters of 1984-1986 and 2003-2005. They found that the As concentrations in snow decreased from $15 \mu \mathrm{g} \mathrm{L}^{-1}$ in 1984-1986 to $<2 \mu \mathrm{g} \mathrm{L}^{-1}$ in 2003-2005. This decline mirrored the considerable decrease in industrial emissions of As in Central Europe.

HUANG and MATZNEr (2007a) carried out speciation of As in throughfall under Norway spruce in Germany. They found that the highest concentration of arsenate (As, V) $\left(2.03 \mu \mathrm{g} \mathrm{L}^{-1}\right)$ was measured in throughfall. The organic As species had concentrations in throughfall less than $0.1 \mu \mathrm{g}$ $\mathrm{L}^{-1}$. Despite that low concentration, the throughfall deposition together with litterfall seem to be the originator of organic As species in forest floors of unpolluted forests (HuAng and Matzner, 2007c).

The fluxes of As in the hydrological cycle depend on the present and past load of As. Conifer species are offered for As monitoring because they have a unique capacity to trap suspended particles in new and old needles. In a polluted spruce stand in the Czech Republic, Erbanova et al. (2008) calculated a flux of As $22 \mathrm{~g} \mathrm{ha}^{-1} \mathrm{yr}^{-1}$ in the period 1995-2006 in throughfall under spruce, whereas the bulk deposition flux was about $18 \mathrm{~g} \mathrm{ha}^{-1} \mathrm{yr}^{-1}$. In an unpolluted spruce stand, the same authors for the same period found about $4 \mathrm{~g} \mathrm{ha}^{-1} \mathrm{yr}^{-1}$ in throughfall and even less than $3 \mathrm{~g} \mathrm{ha}^{-1}$ $\mathrm{yr}^{-1}$ in the bulk deposition. HuANG and Matzner (2007b) found $4.7 \mathrm{~g} \mathrm{ha}^{-1} \mathrm{yr}^{-1}$ in throughfall and $3.89 \mathrm{~g} \mathrm{ha}^{-1} \mathrm{yr}^{-1}$ of As fluxes in bulk deposition in a spruce stand in Germany having a history of pollution deposition. In all cases, either in polluted or unpolluted forests, the enrichment of throughfall with As is evidence of dry deposition.

\section{Soil water}

Wenzel et al. (2002) measured the concentrations of As in soil solution collected with suction cups from the forest floor and minerals soils in 38 soil pits located across the Austrian central Alps in areas known for large arsenic concentrations in river sediments. In the forest floors they found a median range 4.3 to $68.8 \mu \mathrm{g} \mathrm{L}^{-1}$, whereas in the mineral soil the range was 0.5 to $13 \mu \mathrm{g} \mathrm{L}^{-1}$. The site at which the $68.8 \mu \mathrm{g} \mathrm{L}^{-1}$ of As concentration was measured had a severe pollution past due to a local smelter activities. In a forested site in Germany, which had received high atmospheric pollution loads from industrial sources in the Czech Republic, the soil solution collected with tension lysimeters in the mineral soil had a lower range of As concentration, 0.27 to $2.02 \mu \mathrm{g} \mathrm{L}^{-1}$ in the $20 \mathrm{~cm}$ and 0.033 to $0.632 \mu \mathrm{g} \mathrm{L}^{-1}$ in the $90 \mathrm{~cm}$ depth (HuANG and MatzNer, $2007 b$ ). The authors also collected percolating water (zero 
tension lysimeters) just under the forest floor. They found higher concentrations of As $\left(2.37-7.65 \mu \mathrm{g} \mathrm{L}^{-1}\right)$ than in the depth of $20 \mathrm{~cm}$ with the suction cup. These large differences between the two sites in Germany and the Czech Republic should probably be ascribed on one hand to different As loads and the other to different reduction potentials in soil microsites. Some of the concentrations mentioned above approach or even exceed the value of $10 \mu \mathrm{g} \mathrm{L}^{-1}$ in drinking water set by the WHO. This data was derived from tension lysimeters. There is no data concerning As concentration in soil solution derived from zero tension lysimeters in mineral soil horizons. This should be a subject for further research.

\section{Vegetation}

The majority of research with regard to As content in forest tree parts concerns the needle/leaf analysis. There are few works dealing with other tree parts (bark, wood etc).

WytTENBACH et al. (1996) measured the concentrations of As in the needles of Norway spruce in Switzerland in five age classes after removing the exogenous material (deposited material on leaf surfaces). They found that the exogenous material had higher concentrations than the endogenous one. Remarkably, they found a good correlation between the exogenous and endogenous As concentrations. They ascribed this to the foliar uptake of exogenous As. They also found an accumulation pattern of the endogenous As in the higher age classes. They argued that once As is found inside the leaf cells, it is not translocated to younger tissues and it remains there until the needles are shed to the ground. In the remote mountainous areas, the sum of the average endogenous and exogenous As had a range of 0.02 to $0.03 \mathrm{mg} \mathrm{kg}^{-1}$. In unwashed needles of Bulgarian fir trees in Greece Michopoulos et al. (2018) found similar concentrations in the first age classes $\left(0.026-0.042 \mathrm{mg} \mathrm{kg}^{-1}\right)$ but higher ones in the rest of the classes $\left(0.117 \mathrm{mg} \mathrm{kg}^{-1}\right)$. In washed two years needles in Slovakia of Norway spruce, MANKOvsKA (1997) measured an As concentration of $1.41 \mathrm{mg} \mathrm{kg}^{-1}$ and in leaves of beech $0.67 \mathrm{mg} \mathrm{kg}^{-1}$ (also washed).

LIN et al. (1995) determined the As content in both washed and unwashed needles of Balsam fir (Abies balsamea (L.) Mill.) in Canada. They found that the two concentrations differed significantly. The washed plant material had a concentration of 0.002 to $0.005 \mathrm{mg} \mathrm{kg}^{-1}$, whereas the unwashed one had a surplus of $0.014 \mathrm{mg} \mathrm{kg}^{-1}$. It seems that the epicuticular wax on conifer needle surfaces retains As associated with aerosols and that As fraction can account to more than $60 \%$ of the total concentration (WYTTENBACH et al., 1990). ERBANOva et al. (2008) found that dry deposition amounted to $45 \%$ of total As deposition in polluted spruce stands in the Czech Republic. The question that arises is to wash or not wash before analysis. The answer probably depends on the purpose of the analysis. If the objective is to find the real uptake of As into the plant cells, washing should be preferred. If however, the purpose is to estimate the ability of needles to reflect levels of atmospheric dry deposition, then the needles should re- main as they were collected prior to analysis (ČEBURNIS and STEINNES, 2000). The latter authors in unwashed needles of Norway spruce on Lithuania found a median concentration of As $0.06 \mathrm{mg} \mathrm{kg}^{-1}$ with a range of 0.03 to $0.10 \mathrm{mg} \mathrm{kg}^{-1}$. Interestingly they determined almost identical values for As in the needles of the common Juniper (Juniperus communis L.). They also found that conifer needles consistently showed lower concentrations of As (and heavy metals) than mosses collected at the same site. They argued that mosses were clearly preferable as biomonitors because of their higher elemental concentrations $\left(0.40 \mathrm{mg} \mathrm{kg}^{-1}\right.$ for As) and more quantitative reflection of deposition rates. In contaminated sites the As uptake by forest species can be high. CHeng et al. (2007) measured the concentrations in various parts of the species post oak (Quercus stellata Wangenh.), white oak (Quercus alba L.), pitch pine (Pinus rigida Mill.), eastern red cedar (Juniperus virginiana L.) and pignut hickory (Carya glabra Mill.) growing in soils containing 8-500 $\mathrm{mg} \mathrm{kg}^{-1}$. After removing (with water) the dust from the leaves they found much higher concentrations in the leaves of conifers $\left(3.14-3.64 \mathrm{mg} \mathrm{kg}^{-1}\right)$, whereas the broadleaves had a range of 0.29 to $0.45 \mathrm{mg} \mathrm{kg}^{-1}$. They attributed this big difference to the efficiency the canopy of conifers has to trap aerosols.

Apart from leaves, the tree part that is of interest is the bark. Its content of some metalloids such as As and heavy metals reflects the pollution condition of an area (ChrabąSzCz and Mróz, 2017). Cheng et al. (2007), in the work mentioned above, found high concentrations of As (up to $2.75 \mathrm{mg} \mathrm{kg}^{-1}$ ) in bark samples of oak and cedar in contaminated sites, whereas in the control areas (no contamination) the top concentration was $0.09 \mathrm{mg} \mathrm{kg}^{-1}$. SCHELLE et al. (2008) analyzed bark samples from the area of Sheffield in England, a city with a long tradition of iron smelting and the production of steel. They collected samples of bark from 642 trees of the three species (with proportions of each shown in parentheses): sycamore (Acer pseudoplatanus L., 68\%), oak (Quercus robur L., 22\%) and cherry (Prunus serrula Franch, 10\%). The As content had a mean of $3.65 \mathrm{mg} \mathrm{kg}^{-1}$. Bark samples were also collected from sycamore trees at Mace Head on the west coast of Ireland where there was negligible pollution. In these samples the As was no detectable by the analytical instrument (XRF spectrometry). Likewise, Michopoulos et al. (2018) found no detectable As in the bark of Bulgarian fir (ICP instrument).

\section{Litterfall}

The As concentrations in litterfall is generally higher than those in leaves of standing vegetation. That is especially pertinent for conifers because the litterfall may have been derived from 5 to 10 years old needles. In Norway spruce in the area of Bavaria in Germany, near the industrial region of the Czech Republic, the median concentration of As in foliar litterfall was $0.316 \mathrm{mg} \mathrm{kg}^{-1}$ (HuANG and MATZNER, 2007b). In a remote unpolluted area in central Greece, the average concentration of As in foliar litterfall in a Bulgarian fir stand was very similar $\left(0.354 \mathrm{mg} \mathrm{kg}^{-1}\right)$ 
(Michopoulos et al., 2018). Interestingly, the other fractions of litterfall of the Bulgarian fir like pollen, insect frass (droppings), lichens and mosses had higher concentrations of As $\left(0.600-0.795 \mathrm{mg} \mathrm{kg}^{-1}\right)$ than those in needles. The last fractions have far higher surface area because their dimensions are close to those of dust. It can be concluded that the As dry deposition stack to this kind of plant part before they became litterfall.

The fluxes of As in foliar litterfall of spruce have been estimated only in the work of HUANG and MATZNER (2007b). They found $0.9 \mathrm{~g} \mathrm{ha}^{-1} \mathrm{yr}^{-1}$, which is lower than the $4.7 \mathrm{~g} \mathrm{ha}^{-1} \mathrm{yr}^{-1}$ found in the throughfall of the same stand. It seems that throughfall is an important path for As to the forest floor.

\section{Soil}

In forest soils, the forest floor is the most active part in terms of biological activity. The most important role with regard to As is the retention of the metal when the latter is deposited from the atmosphere (MATSCHULlat, 2000). In 192 forest sites in the Czech Republic, Suchara and Sucharoví (2002) found that the As concentration went increasing in forest floors towards the most industrialized areas reaching a value of $167 \mathrm{mg} \mathrm{kg}^{-1}$. GAŠOví et al. (2017) also found high concentrations $\left(55.6 \mathrm{mg} \mathrm{kg}^{-1}\right)$ of As in the humus layer of a beech forest $1.5 \mathrm{~km}$ from a smelter in central Slovakia. In contrast, in an unpolluted area MicHOPOULOS et al. (2018) found $5.58 \mathrm{mg} \mathrm{kg}^{-1}$ in the humus layer of a fir forest. Norwegian forest soils are also considered unpolluted and their content in the humus layers had a range $0.4-7.5 \mathrm{mg} \mathrm{kg}^{-1}$ (LAG and Steinnes, 1978). According to GUSTAFSSON and JACKS (1995), the As concentrations in the forest floor reflect the atmospheric deposition. In unpolluted sites the As concentrations of the forest floors are always lower than those in mineral soils. For example in the soil of the fir plot mentioned above (Michopoulos et al., 2018), the total concentrations of the mineral layers down to $80 \mathrm{~cm}$ had a range $8.02-9.47 \mathrm{mg} \mathrm{kg}^{-1}$. HuANG and MATZNER (2007c) found values of 10 to $24 \mathrm{mg} \mathrm{kg}^{-1}$ in the mineral layers of uncontaminated forest soils in Germany. Despite the high retention of As in the forest floor, HuANG and MATZNER (2007b) showed that the retention for soils loaded with high amounts of As is not long termed and the metalloid begins mobilizing and starts migrating in mineral layers. WeNG (2009) argued that an organic fraction in soils with a large molecular weight would retain more effectively As, whereas a more soluble and lighter fraction tends to dissolve the As, either by chelating it or by displacing the anions associated with the metal. Due to the As mobilization, TANG et al. (2015) found that the C horizons of soils in coniferous forests increased in concentrations of As in the period $1990-2013$ from 19.3 to $26.7 \mathrm{mg} \mathrm{kg}^{-1}$. Mobility of As was also found by BLASER et al. (2000) in 23 forested soil profiles in Switzerland. The problem is that during heavy rain events there can be transfer of As from the forest floor to surface waters by superficial flow (ERBANOva et al., 2008; HuANG and MATZNER, 2007b). The mobility of As is caused by an interplay of hydrological conditions and retreating acidification which may mobilize arsenic by competitive ligand exchange (ERBANOva et al., 2008). Phosphates and arsenates are considered chemical analogues, implying that they can substitute for each other in chemical reactions. In biogeochemical reactions, this is often observed, including adsorption/desorption reactions (STRAWN, 2018).

In contrast to other trace elements, As is mobilized when the soil pH increases (MORENO-JIMÉNEZ, 2012). As mentioned above, the most toxic form of As is the arsenite As (III). Under reducing conditions, arsenites are the predominant arsenic compounds (MANDAL and SuZUKI, 2002). Even the most aerobic soil has reduced microsites. Fortunately, the forest floor decreases the concentration of the As(III) by converting it into methylated forms and thus detoxifies the As content in the soil solution. Also the Oi layer is an effective sink for As(III) retaining the $80 \%$ of the As(III) input by oxidation of As(III) to As(V) (HUANG and MATZNER 2007a). It seems that the problem for surface waters is created when there is a high input load of As into the forest floors. Further, down the soil profile, the level of soluble arsenic in soils is determined by the relative arsenic sorptivity of soil components, chiefly iron and aluminum compounds. For example, all of the arsenic added to soils is removed by treatment with oxalate, which also removes iron and aluminum bound in allophonic materials and hydrous oxides (JACOBS et al., 1970). When the As concentration is low, the retention by the soils does not proceed through the precipitation of sparingly soluble arsenate compounds but through adsorption mechanisms. The adsorption maxima of the soils are not related to acidity and the contents of inorganic $\mathrm{C}$, but are linearly related to amounts of ammonium oxalate-extractable $\mathrm{Al}$ and, to a lesser extent, to the contents of clay and ammonium oxalate-extractable Fe (LivESEY and HUANG, 1981).

Table 1 is a concise table containing the total concentrations of As in forest floors and mineral soils of forested sites having different pollution histories. It can serve as a reference to assess the levels of As contamination provided that the particular characteristics of any soil under consideration are taken into account.

\section{Conclusions}

Despite the decline in the As inputs to forests, the sites having received heavy loads of As in the past years, for example from coal fired plants, can mobilize the metal in the runoff waters especially after heavy rains. The mechanisms of the mobilization are not exactly clear. Organic matter of low molecular weight, retreating acidification, or reducing conditions in soil microsites may be some reasons. The effect of climate change should be a subject of research. In unpolluted soils the forest floor together with the oxides of $\mathrm{Fe}$ and $\mathrm{Al}$ in the mineral layers retain the As inputs efficiently. In some forests, having pollution past, the concentrations of As in soil solution, obtained with suction cups approach, or even exceed the thresholds set by the World Health Organization. Zero tension lysimeters should also be used for comparison reasons. 
Table 1. Total concentrations $\left(\mathrm{mg} \mathrm{kg}^{-1}\right)$ of As in organic horizons and mineral soils in various forested sites having different pollution histories

\begin{tabular}{|c|c|c|c|c|c|}
\hline Layer & Site & Vegetation & $\begin{array}{c}\text { Pollution } \\
\text { history }\end{array}$ & As & References \\
\hline $\mathrm{H}$ & $\begin{array}{c}\text { Fichtelbirge } \\
\text { mountains, Germany }\end{array}$ & Picea abies & NO & $2-18$ & HUANG and MATZNER, 2007c \\
\hline $\mathrm{H}$ & $\begin{array}{c}\text { Erzgebirge } \\
\text { Mountains, Germany }\end{array}$ & Pinus sylvestris & YES & 1,700 & HUANG AND MATZNER, 2007C \\
\hline $\mathrm{H}$ & Central Greece & Abies borisii regis & NO & 5.58 & Michopoulos et al., 2018 \\
\hline $\mathrm{H}$ & $\begin{array}{l}\text { Northern Czech } \\
\text { Republic }\end{array}$ & Picea abies & YES & 40 & NovaK et al. 2011 \\
\hline $\mathrm{H}$ & $\begin{array}{l}\text { Southern Czech } \\
\text { Republic }\end{array}$ & Picea abies & NO & 10 & NovaK et al., 2011 \\
\hline $\mathrm{H}$ & $\begin{array}{c}\text { South west Czech } \\
\text { Republic }\end{array}$ & Coniferous sp. & YES & $39.4-50.8$ & SUCHARA and SUCHAROVÁ, 2002 \\
\hline $\mathrm{H}$ & $\begin{array}{l}\text { Southern Czech } \\
\text { Republic }\end{array}$ & Coniferous sp. & NO & $10-11.6$ & SUCHARA and SUCHAROVÁ, 2002 \\
\hline $\mathrm{H}$ & Southern Norway & Coniferous sp. & NO & $2.5-7.5$ & LAG and STEINNES, 1978 \\
\hline $\mathrm{H}$ & Tibet plateau, China & Coniferous sp. & NO & $5.0-41.2$ & TANG et al., 2015 \\
\hline $\mathrm{H}$ & Central Slovakia & Fagus sylvatica & YES & 55.6 & GAŠOVÁ et al., 2017 \\
\hline $\mathrm{H}$ & Northern Sweden & Coniferous sp. & YES & $54-520$ & GUSTAFFSON and JACKS, 1995 \\
\hline $\mathrm{H}$ & Northern Sweden & Coniferous sp. & NO & $1.3-19.0$ & GUSTAFFSON and JACKS, 1995 \\
\hline Mineral soil & Tibet plateau, China & Coniferous sp. & NO & $11.5-59.2$ & TANG et al., 2015 \\
\hline Mineral soil & $\begin{array}{c}\text { Fichtelbirge } \\
\text { mountains, Germany }\end{array}$ & Picea abies & NO & $10-24$ & HUANG and MATZNER, 2007 \\
\hline Mineral soil & $\begin{array}{c}\text { Erzgebirge } \\
\text { mountains, Germany }\end{array}$ & Pinus sylvestris & YES & $50-4,000$ & HUANG and MATZNER, 2007 \\
\hline Mineral soil & New Jersey, USA & $\begin{array}{l}\text { Quercus and } \\
\text { Pinus sp. }\end{array}$ & YES & $4.1-662$ & CHENG et al., 2007 \\
\hline Mineral soil & New Jersey, USA & $\begin{array}{l}\text { Quercus and } \\
\text { Pinus sp. }\end{array}$ & NO & $1.6-5.5$ & CHENG et al., 2007 \\
\hline
\end{tabular}

In either polluted or unpolluted sites, the conifer species with needles of different ages can confirm the presence of As in dry deposition form.

\section{Acknowledgements}

The author wishes to thank all researchers who had articles published with regard to the role of As in forests. Without that information, the present review would have been impossible.

\section{References}

Abbas, G., Murtaza, B., Bibi, I., Shahid, M., Niazi, N.K., Khan, M.I., Amjad, M., Hussain, M., Natasha., 2018.
Arsenic uptake, toxicity, detoxification, and speciation in plants: physiological, biochemical, and molecular aspects. International Journal of Environmental Research and Public Health, 15: 59.

Bauer, M., Blodau, C., 2009. Arsenic distribution in the dissolved, colloidal and particulate size fractions of experimental solutions rich in dissolved organic matter and ferric iron. Geochimica et Cosmochimica Acta, 73: 529-542.

Blaser, P., Zimmermann, S., Luster, J., ShotyK, W., 2000. Critical examination of trace element enrichments and depletions in soils: $\mathrm{As}, \mathrm{Cr}, \mathrm{Cu}, \mathrm{Ni}, \mathrm{Pb}$ and $\mathrm{Zn}$ in Swiss forest soils. Science of the Total Environment, 249: 257-280.

BIENERT, G.P., JAHN, T.P., 2010. Major intrinsic proteins and arsenic transport in plants: new players and their potential role. Advances in Experimental Medicine and Biology, 679: 111-126. 
Kinniburgh, D.G., Smedley, P.L. (eds), 2001. Arsenic contamination of groundwater in Bangladesh. British Technical report (British Geological Survey), WC/00/19. Keyworth: British Geological Survey. 4 vol.

Cheng, Z., Buckley, B.M., Katz, B., Wright, W., Bailey, R., Smith, K.T., Li, J., Curtis, A., van Geen, A., 2007. Arsenic in tree rings at a highly contaminated site. Science of the Total Environment, 376: 324-334.

Chrabąszcz, M., Mróz, L., 2017. Tree bark, a valuable source of information on air quality. Polish Journal of Environmental Studies, 26: 453-466.

Čeburnis, D., Steinnes, E., 2000. Conifer needles as biomonitors of atmospheric heavy metal deposition: comparison with mosses and precipitation, role of the canopy. Atmospheric Environment, 34: 4265-4271.

Cullen, W.R., Reimer, K.J., 1989. Arsenic speciation in the environment. Chemical Reviews, 89: 713-764.

Doušová, B., Erbanová, L., Novák, M., 2007. Arsenic in atmospheric deposition at the Czech-Polish border: Two sampling campaigns 20 years apart. Science of the Total Environment, 387: 185-193.

Erbanova, L., NovaK, M., Fottova, D., Dousova, B., 2008. Export of arsenic from forested catchements under easing atmospheric pollution. Environmental Science and Technology, 42: 7187-7192.

Gašová, K., Kuklová, M., KuKla, J., 2017. Contents of nutrients and arsenic in litterfall and surface humus in mature nodal beech stands subjected to different emissionimmission loads. Folia Oecologica, 44: 11-19.

GustafFSON, J.P., JACKs, G., 1995. Arsenic geochemistry in forested profiles as revealed by solid-phase studies. $A p$ plied Geochemistry, 10: 307-315.

Harmens, H., Norris, D.A., Koeber, G.R., Buse, A., SteINNES, E., RŸHLING, Å., 2007. Temporal trends in the concentration of arsenic, chromium, copper, iron, nickel, vanadium and zinc in mosses across Europe between 1990 and 2000. Atmospheric Environment, 41: 6673-6687.

Harmens, H., Norris, D.A. et al., 2015. Heavy metal and nitrogen concentrations in mosses are declining across Europe whilst some "hotspots" remain in 2010. Environmental Pollution, 200: 93-104.

Huang, J.H., MatzNER, E., 2007a. Fluxes of inorganic and organic arsenic species in a Norway spruce forest floor. Environmental Pollution, 149: 201-208.

Huang, J.H., Matzner, E., 2007b. Biogeochemistry of organic and inorganic arsenic species in a forested catchment in Germany. Environmental Science and Technology, 41: 1564-1569.

HuAng, J.H., MatzNer, E., 2007c. Mobile arsenic species in unpolluted and polluted soils. Science of the Total Environment, 377: 308-318.

Jacobs, L.W., Syers, J.K., KeEney, D.R., 1970. Arsenic sorption by soils. Soil Science Society of America Journal, 34: $750-754$.

Kabata-Pendias, A., Pendias, H., 2000. Trace elements in soils and plants. Boca Raton, Florida: CRC Press. 315 p.

Koch, I., Wang, L., Ollson, C.A., Cullen, W.R., Reimer, K.J., 2000. The predominance of inorganic arsenic species in plants from Yellowknife, Northwest Territories, Canada. Environmental Science and Technology, 34: $22-26$.
LAG, J., STEINNES, E., 1978. Regional distribution of selenium and arsenic in humus layers of Norwegian forest soils. Geoderma, 20: 3-14.

Lin, Z.Q., SchuepP, P.H., Schemenauer, RS., Kennedy, G.G., 1995. Trace metal contamination in and on balsam fir (Abies balsamea (1) Mill.) foliage in southern Quebec, Canada. Water, Air and Soil Pollution, 81: 175-191.

Livesey, N.T., Huang, P.M., 1981. Adsorption arsenate by soils and its relation to selected chemical properties and anions. Soil Science, 131: 88-94.

Mandal, K.M, SuzuKi, K.T., 2002. Arsenic round the world: a review. Talanta, 58: 201-235.

Mankovska, B., 1998. The chemical composition of spruce and beech foliage as environmental indicator in Slovakia. Chemosphere, 36: 949-953.

Matschullat, J., 2000. Arsenic in the geosphere - a review. Science of the Total Environment, 249: 297-312.

Meharg, A.A., Hartley-Whitaker, J., 2002. Arsenic uptake and metabolism in arsenic resistant and non-resistant plant species. New Phytologist, 154: 29-43.

Michopoulos, P., Bourletsikas, A., KaOUKis, K., Daskalakou, E., Karetsos, G., Kostakis, M., Thomaidis, N.S., Pasias, I.N., Kaberi, H., Iliakis, S., 2018. The distribution and variability of heavy metals in a mountainous fir forest ecosystem in two hydrological years. Global NEST Journal, 20: 188-197.

Moreno-Jiménez, E., Esteban, E., Peñalosa, J.M., 2012. The fate of arsenic in soil-plant systems. In WhitACRE, D.M. (ed.). Reviews of Environmental Contamination and Toxicology, 215. New York: Springer New York, p. 1-37.

NovaK, M., Erbanova, L., Fottova, D., Cudlin, P., Kubena, A., 2011. Behaviour of arsenic in forested catchments following a high-pollution period. Environmental Pollution, 159: 204-211.

Nygard, T., Steinnes, E., Rayset, O., 2012. Distribution of 32 elements in organic surface soils: contributions from atmospheric transport of pollutants and natural sources. Water, Air and Soil Pollution, 223: 699-713.

Panda, S.K., Upadhyay, R.K., NATH, S., 2010. Arsenic stress in plants. Journal of Agronomy and Crop Science, 196: 161-174.

Pradosh, R., Saha, A., 2002. Metabolism and toxicity of arsenic: a human carcinogen. Current Science, 82: 38-45.

Punshon, T., Jacson, B.P., Meharg, A.A., Warczack, T., SCHECKel, K., GuerinOt, M.L., 2017. Understanding arsenic dynamics in agronomic systems to predict and prevent uptake by crop plants. Science of the Total Environment, 581-582: 209-220.

Schelle, E., Rawlins, B.G., LARK, R.M., Webster, R., StaTON, I., MCLeOD, C.W., 2008. Mapping aerial metal deposition in metropolitan areas from tree bark: a case study in Sheffield, England. Environmental Pollution, 155: 164-173.

Smedley, P.L., Kinniburgh, D.G., 2002. A review of the source, behavior and distribution of arsenic in natural waters. Applied Geochemistry, 17: 517-568.

Steiness, E. Friedland, A.J., 2005. Metal contamination of natural surface soils from long-range atmospheric transport: existing and missing knowledge. Environmental Reviews, 14: 169-186. 
STRAWN, D.D., 2018. Review of interactions between phosphorus and arsenic in soils from four case studies. Geochemical Transactions, 19: 10.

Suchara, I., Sucharová, J., 2002. Distribution of sulphur and heavy metals in forest floor humus of the Czech Republic. Water, Air and Soil Pollution, 136: 289-316.

Tang, R., Wang, H., Luo J., Sun, S., Gong, Y.,She, J., Chen, Y., Dandan, Y., Zhou, J., 2015. Spatial distribution and temporal trends of mercury and arsenic in remote timberline coniferous forests, eastern of the Tibet Plateau, China. Environmental Science and Pollution Research, 22: $11658-11668$.

Van Herrewghe, S., Swennen, R., Vandecasteele, C., CAPPuYns, V., 2003. Solid phase speciation of arsenic by sequential extraction in standard reference materials and industrially contaminated soil samples. Environmental Pollution, 122: 323-342.

(WHO) World Health Organization, 2020. Arsenic. [cit. 202010-02]. https://www.who.int/news-room/fact-sheets/detail/arsenic
Weng, L., VAn RiemsdijK, W.H., Hiemstra, T., 2009. Effects of fulvic acids on arsenate adsorption to goethite: experiments and modelling. Environmental Science and Technology, 43: 7198-7204.

Wenzel, W.W., Brandstetter, A., Wutte, H., Lombi, E., Prohaska, T., Stingeder, G., Adriano, D.C., 2002. Arsenic in field-collected soil solutions and extracts of contaminated soils and its implication to soil standards. Journal of Plant Nutrition and Soil Science, 165: 221-228.

Wyttenbach, A., Bajo, S., Tobler, L., 1990. Major and trace elements in spruce needles by NAA. In ScHraUzER, G.N., (ed.). Biological trace element research. Clifton, UK: Humana Press, p, 213-221.

Wyttenbach, A., Bajo, S., Tobler, L.A., 1996. Arsenic concentrations in successive needle age classes of Norway spruce (Picea abies [L.] Karst.). Fresenius Journal of Analytical Chemistry, 354: 668-671.

Received November 2, 2020

Accepted November 18, 2020 